\title{
International-level Cultural Diplomacy: Analysis of the Polewali Mandar International Folk and Art Festival (PIFAF) in The International Relations Perspective
}

\author{
Asma Amin ${ }^{1}$, Andi Ismira ${ }^{2}$ \\ \{asmaamin@unsulbar.ac.id ${ }^{1}$, andi.ismira@unsulbar.ac.id ${ }^{2}$ \} \\ 1,2 Departement of International Relations, Universitas Sulawesi Barat, \\ Jl. Prof. Dr. H. Baharuddin Lopa, SH., Majene, West Sulawesi, 91412, Indonesia.
}

\begin{abstract}
This study aims to analyze the Polewali Mandar International Folk and Art Festival (PIFAF) event based on International Relations perspectives as a culture diplomacy designed by government of Polewali Mandar Regency (Youth, Sports and Tourism Office) in international level. The study used qualitative research methods through primary and secondary data through three methods: interviews; document-based research; and internet-literature research. The Data used between year 2016-2018. The results showed that PIFAF's effective soft power for the Polewali Mandar District Government introduced and preserved the cultural arts of the Mandar tradition and at the same time as a promotion or cultural diplomacy in attracting local and foreign tourists to Polewali Mandar. The PIFAF implementation shows the interaction between multi actors who cross national boundaries and are able to produce a multipplier effect for all parties, both in the form of culture/art values and commercial values. At present, the PIFAF is included in the 100 wonderfull Indonesia Calendar of Events and list of festivals CIOFF.
\end{abstract}

Keywords: PIFAF, Polewali Mandar, Cultural Diplomacy, International Relation, Soft Power

\section{Introduction}

Discussion of the correlation between culture and diplomacy has been carried out since the beginning of civilization, but the study of international relations has put a little attention to the existence of culture, compared to political and economic perspectives [1]. This is closely related to the development of traditional international relations approaches that focus more on high issues such as politics and war. The shift in the study of international relations towards non traditionalist soft issues has provided space for contemporary diplomacy that allows diplomacy practitioners and practitioners to widen the scope of diplomacy which is marked by the development of fields of diplomacy such as economic, military, e-diplomacy and cultural diplomacy [2].

The historical legacy of cold war has given a negative connotation to cultural diplomacy because it is considered as an activity of manipulation of cultural material and agents of cultural diplomacy for propaganda purposes, so it is often interpreted the same as propaganda itself. Cultural diplomacy is also often exchanged as "public diplomacy" and "cultural exchange", [3],[4]. According to the US Department of State 1959, cultural diplomacy is "direct and enduring" 
contact between peoples of different nations "designed to" help create a better climate of international trust and understanding which official relations can operate [5]. Cultural diplomacy uses cultural elements as its main capital or cultivation and naturally provides space for more active participation, including actors other than the state such as (but not limited to) sub-state actors, private organizations, international organizations, academics, philanthropists, missionaries and art performers in carrying out cultural missions, while their forms can take the form of activities of exchanging education, art, and popular culture such as literature, music and films, and performances of traditional cultural arts or traditional arts.

The implementation of this cultural diplomacy was also carried out by the Polewali Mandar District Government, through Youth, Sports and Tourism Office (sub state actor), by carrying out activities titled Polewali Mandar International Folk and Art Festival or abbreviated as PIFAF. PIFAF is a traditional cultural and cultural exchange activity between nations that presents various cultural arts activists/traditions from Indonesia and from abroad. This activity began in 2016 and has become an annual routine held every 1-6 August in Polewali Mandar District. Since its inception in 2016, PIFAF has succeeded in presenting 5 countries, including: South Korea, Russia, Malaysia, Romania and India [6]. Whereas in 2017, the number of countries involved increased dramatically, namely 17 countries: Britain, Spain, Finland, Netherlands, Russia, Portugal, Germany, France, Vietnam, China, Hong Kong, Morocco, Slovakia, Malaysia, Thailand, South Korea and India [7]. Furthermore, in 2018, the countries involved were only 6 countries, namely, Latvia, Croatia, China Taipei, Mexico, Thailand and Poland [8].

Given the increasing role of culture in international diplomacy, a special study is needed to analyze the forms of cultural diplomacy in PIFAF activities, as well as the benefits generated from these activities which will be analyzed in three parts. First, the PIFAF analysis as a soft power. Second, the synergy of multy actors and multiplier effects in implementing the PIFAF. Third, cultural values and commercial values in implementing cultural diplomacy through PIFAF.

\section{Methods}

In this study, the method used is a qualitative method. Qualitative methods are exploratory research [9]. Qualitative methods generally refer to data collection and data analysis strategies or techniques that depend on non-numeric data. This method is used to get a better understanding of how we understand the world around us or about the reasons, opinions and motivations that underlie a behavior [10]. The main objective of qualitative research is to provide a detailed and complete explanation of the research topic [9]. In this study the main goal to be achieved is to analyze the PIFAF as a model of cultural diplomacy carried out by the Regional Government of Polewali Mandar District through Youth, Sports and Tourism Office.

This research is limited in the period 2016-2018 by emphasizing data collection through various methods, namely: interview method; document-based research; and internet based research. The results of this data collection are then accumulated and analyzed so that the data can be generalized. 


\section{Discussion}

\subsection{PIFAF: A Soft Power in Regional Cultural Diplomacy}

In the science of international relations, power is the main element, where in the eyes of realism, state behavior is basically a struggle for strength or a struggle for power [11]. Power is divided into 2 forms, namely hard power and soft power. Hard power is a direct form of power utilization, both with a pattern of coercive (reward) approach and reward (gift giving) [12]. In principle hard power has a transactional character and a combination of organizational capabilities (power and information management) and machiavelis (the ability to threaten and build victory coalitions) [13]. Soft Power has an inspirational character, namely the power to attract other people with the power of emotional intelligence such as building close relationships or ties through charisma, persuasive communication, the attractiveness of visionary ideologies, and cultural influences, thus making others affected [14].

Based on this definition, it is appropriate to position the Polewali Mandar International Folk and Art Festival (PIFAF) event as a soft power. PIFAF uses cultural elements with the aim of promoting Polewali Mandar's culture, people and tourism potential in international forums. This is evident in the PIFAF where participants consisting of local tradition artists and traditional artists from other countries will take part in various activities packed by committees which become a medium for the introduction of Polewali Mandar's culture, humanity and tourism. These activities include: parade; workshop; the performance of (cultural) arts such as dance, music, folk games; the appearance of cultural arts (outdoor) such as street dance; visits to several tourist attractions; tree planting, turtle release, exchange gift, discussion and study of art and culture between nations; bazaar and traditional mandar cuisine; gathering and various other activities $[6,7,8]$.

Interestingly, the orientation of the implementation of this PIFAF activity was more inclined than outward looking to inwardlooking. It is different from various models of cultural promotion or diplomacy that are generally carried out by governments, organizations or cultural arts activists who have more to do performances abroad, with the aim of introducing local/Indonesian cultural arts abroad. This model, besides being difficult, is very costly and the scope of the scope is narrower. In the end, the performances are more often performed indoors, hotels, embassies or carried out at certain events and most likely will only be enjoyed by Indonesians who are abroad and perhaps a few foreigners. Unlike the PIFAF, the orientation is outwardlooking-inwardlooking-outwardlooking, which is to bring art activists from abroad to come to Indonesia-Polewali Mandar in order to take part in PIFAF activities. Furthermore, these traditional artists will introduce their traditional art through various performances (indoor \& outdoor) while enjoying and being introduced to the local traditional arts of culture, culture, natural potential, interacting with the community and of course knowing more about Polewali Mandar through various activities that packed by the committee. Furthermore, outside participants will be tourism promotion agents (endorsers) directly or indirectly through photos, hashtags, captions, statuses or stories on social media they have [15]. it means that the promotion and diplomacy carried out is increasingly widespread and effective. 


\subsection{Synergy of Multi-Actor \& Multiplier Effect}

The Polewali Mandar International Folk and Art (PIFAF) event involves a synergy of multi actor (domestic and foreign) and has proven to provide a multiplier effect (direct or indirect) for all parties. The actors involved can be divided into several parts. First, the sub state actor, the PIPAF executive committee, namely the Polewali Mandar District Government, in this case: Youth, Sports and Tourism (Dipop) of Polewali Mandar Regency. In addition, the West Sulawesi Provincial Government is involved in funding. In the implementation of the PIFAF, funding was sourced from the Regional Budget of Regional Revenue and Expenditure (APBD) of the District of Polewali Mandar and Special Financial Assistance (SFA) of the West Sulawesi Province and the assistance of non-binding third parties (sponsors). For 2019, the Ministry of Tourism will provide financial assistance for the implementation of the PIFAF as an appreciation of the success and continuity of the implementation of the PIFAF consistently every August 1-6 each year. The success of PIFAF helped increase the prestige of the Polewali Mandar Youth, Sports and Tourism Office at the local, national to foreign levels [16].

Secondly, Artists, Culture and Art Community from Polewali Mandar Regency. Through this PIFAF, these traditional artists are given space and experience to express themselves in international forums, introduce traditional art of Mandar, introduce their communities and especially build networks of cooperation among fellow art conservationisy. The implementation of the PIFAF has proven to be able to encourage and arouse local arts and culture which is the basic capital of tourism. This has been proven since the existence of the PIFAF, a dance studio in Polewali Mandar Regency which initially only numbered 8 art studios, has increased to 30 art studios in 2018. In addition, the number of registrants of the Art Community who will be involved in the PIFAF each year is increasing. The executive committee even had to reject and select the number of local and national art communities who registered in the PIFAF activities because the numbers were increasing, but lodging/hotels that could be used were very limited [16].

Third, the international organization of art activists, Coensel International des Organizations de Festival de Folklore et Arts Traditionneils (CIOFF). CIOFF is an international non-profit organization engaged in the implementation of international art and folklore festivals. CIOFF has a dream of spreading peace in Indonesia and through out the world and is the center of the exchange and preservation of the arts and culture of the nation and sends a positive message to the young generation to love and uphold traditions and spread them [17]. The Polewali Mandar Regency Government and CIOFF have signed a memorandum of understanding Number: P.293 / Disbudpar / Bupati /430/03/2016 dated March 10, 2016 and Number: 1280 / SP / CIOFF / 10/3/2016 dated March 10, 2016 concerning cooperation implementation Polewali Mandar International Folk and Art Festival (PIFAF) [8]. In implementing PIFAF, CIOFF was instrumental in helping implement the PIFAF [18] as well as opening registrations for art communities from various countries joined in CIOFF through the official CIOFF website. In addition, CIOFF regulates the standards for implementing PIFAF activities, such as rules that apply internationally that must be complied with by the organizing committee and participants, such as hotel standards provided by the committee for PIFAF participants from abroad. In addition, CIOFF also promoted the PIFAF activities through the official CIOFF web and has included the PIFAF in the CIOFF list of festivals (www.cioff.org). 
Fourth, Artistic activist from abroad. Since the implementation of the PIFAF in 2016 until 2018, there have been 22 foreign traditional arts groups involved in the PIFAF. Generally dominated by Europe, and Asia. Their goals are in line with our goals, namely to promote and maintain the traditional arts of each region. In the implementation of the PIFAF, they were also given the opportunity to introduce and perform traditional arts performances from their country both indoor and street dance (outdoor). In addition, they were also given the opportunity to take part in workshops at various schools and universities in Polewali Mandar with the agenda of performing arts in front of students \& students, introducing about their country, traditional clothes and sharing information regarding the arts community and their country. In this activity, there are mutual benefits from both parties. Students and the general public have knowledge of arts and culture from other countries, the opportunity to interact with foreigners, a place to practice English for students/students. On the other hand, the host has the same opportunity to introduce their regional specialties such as traditional food, traditional dance and music, folk songs, tourist attractions, souvenirs and so on.

Not only that, through this event, participants from abroad will become endorsers in introducing Polewali Mandar and Indonesian art, culture and tourism in general to families, friends and communities in their home countries, both directly and through social media. And this is actually the most effective cultural promotion because of its reciprocity and all actors eventually become agents of tourism promotion to those around them directly or through their social media. There are still many other actors who indirectly succeed the PIFAF and realize its goals, as a small example of visitors / viewers from various regions who came to witness the PIFAF, we can be sure to promote PIFAF and Polewali Mandar through various photos and their posts on social media.

In the PIFAF activities, it is evident that the role and synergy of multi-actors, both domestic and foreign, have provided a multiplier effect for each party involved. The benefits obtained not only touch the parties directly involved and achieve culture/art values, but in the end will have a positive impact on the Polewali Mandar community through commercial values which will eventually lead to public welfare [19].

\subsection{Cultural Diplomacy $=$ Cultural Values + Commercial Values}

The tourism market is growing very rapidly, with a large captive market, both domestic and foreign tourists. The refore, it is very appropriate if Polewali Mandar begins to place Tourism as one of the leading sectors in development. To support this, the PIFAF was carried out with the main objective as "promotion" [18] or cultural diplomacy, in order to introduce Polewali Mandar District to the international level. And it is evident that tourism has very positive characteristics "increasingly preserved, increasingly prospering" [17]. This is evident in the implementation of the PIFAF which is able to produce culture / art values, as well as commercial values.

Culture/art values are the main characteristic of the PIFAF implementation it self. In accordance with the theme stretched every year "introduce the country, preserve tradition". Polewali Mandar Regency strives to foster international trust in Indonesia and Polewali Mandar in particular and to support the program of world peace missions through bridges of cultural interaction between nations. The PIFAF has proven effective in introducing, preserving the cultural arts of the Mandar tradition which was not too glimpsed, perhaps even being eroded by outside culture in its native land. At present, the development of the art community in Polewali 
Mandar District is experiencing a sharp increase every year. From the external side, the presence of participants from abroad has a multiplier effect on the development of folk art and tourism. Their presence with the mission of traditional arts can be useful for local traditional arts activists in Polewali Mandar district as a comparative media, acculturation and at the same time building international relations with traditional arts activists.

Judging from commersial values, this is inseparable from the fact that at present, the Tourism sector is the second largest contributor of foreign exchange after crude palm oil. The tourism sector is one of the largest and fastest growing industries in the world and is considered a potential driver of the national economy to spur higher economic growth in the future. This is because the tourism sector is able to provide positive effects in other fields to develop, such as the hotel, culinary, transportation, trade and so on.

Commercial values generated from the implementation of the PIFAF can be seen from the following data. The number of visitors and viewers during the 2018 PIFAF activities took place around 200,000-270,000. Visitors came from Polewali Mandar District, Majene Regency, Mamasa Regency, Mamuju Regency, Central Mamuju and North Mamuju (West Sulawesi Province) and from Pindrang District, Sidendreng Rappang Regency, Pare-pare City and Makassar City (South Sulawesi Province) and also from East Kalimantan Province with the location of these activities within the Polewali Mandar district [20].

Amount of financial transactions during 2017 PIFAF activities, around Rp. 2,200,000,000 (two billion two hundred million rupiah) originating from entertainment services and rides, eating and drinking transactions, information technology transactions, automotive transactions, general trade transactions, property transactions, parking service transactions and land leases, entertainment facilities rental services, accommodation services, and transportation of publication and documentation services as well as other service rental fee transactions [21].

In the 2018 PIFAF, the number of financial transactions doubled around Rp.5,500,000,000 (five billion five hundred million rupiahs) originating from entertainment services and rides, eating and drinking transactions, information technology transactions, automotive transactions, general trade transactions, property transactions, parking and land leasing services, entertainment facilities, accommodation and transportation services, publication and documentation services and other lease service transaction fees.

From the data above, it shows that the benefits of implementing the PIFAF are not only within the scope of culture value, but also have a large effect on the economic sector of the Polewali Mandar Regency, which is engaged in various sectors which will ultimately lead to increasing community welfare. If we benchmark it to various foreign countries, then we can see that the country/city can be famous because of an event or festival like the PIFAF. Domestically the name Jember sticks to the world map of tourism because it consistently carries out the Jember Fashion Carnival, as well as Banyuwangi, whose people are growing and prosperous because of the many events or festivals held in a year such as Banyuwangi Ethno Carnival. Likewise, Polewali Mandar International Folk and Art has proven to be a calculated tourist destination to the international level. At present, the PIFAF is included in the 100 Wonderful Indonesia Calendar of Events and List of Festivals CIOFF. The consistency of the implementation of the PIFAF will not close the possibility of making Polewali Mandar become a "top-of mind" for tourists and as a "must-visit destination" which can still preserve the cultural arts of its traditions while generating economic 
benefits for all parties and ultimately expected to improve people's welfare in Polewali Mandar District.

\section{Conclusion}

Polewali Mandar International Folk and Art Festival (PIFAF) is a form of cultural diplomacy and an effective international-scale promotion strategy in an effort to preserve, preserve and promote traditional cultural arts that are followed by a community of art tradition activists between nations. By involving multy actor cooperation, PIFAF acts as a soft power in order to foster international trust in Indonesia, especially Polewali Mandar and support the world peace mission program through bridges of cultural interaction between nations. In addition, the PIFAF is proven to provide a multiplier effect for all parties, by producing culture / art values and at the same time commercial values for many parties. This can be seen through the number of visitors in the 2018 PIFAF around 200,000-270,000 people and the number of financial transactions that revolved during the PIFAF activities took place increasing from 2.2 billion in 2017 to 5.5 billion in the 2018 PIFAF. This transaction was accumulated from entertainment service transactions and game rides, eating and drinking transactions, information technology transactions, automotive transactions, general trade transactions, property transactions, parking services and land leasing transactions, entertainment facilities, accommodation and transportation services, publication and documentation services and other leasing services. With the presence of culture / art values and commercial values, it is hoped that this will lead to the welfare of the people of Polewali Mandar Regency.

Acknowledgment. Thank you to Kemenristek Dikti for giving us support \& opportunity through the Beginner Lecturer Research (BLR) scheme. To the Polewali Mandar District Office of Youth, Sports and Tourism Services for their assistance during the conduct of our research. To Our Institution, University of West Sulawesi, for moral support for all lecturers in increasing their capacities and abilities, as well as for colleagues in the discussion room which is always wide open in sharing knowledge and knowledge. A big thank you to the Polewali Mandar District Youth, Sports and Tourism Office for their assistance during the conduct of our research. Hopefully all our activities in carrying out their duties and responsibilities can benefit the general public.

\section{References}

[1] Scheneider, Chyntia, P.: Cultural Diplomacy: Hard to define, but You'd know it if you saw it. The Brown Journal of World Affairs. Fall/Winter.Vol.XIII. Issues I. pp.1, 2006.

[2] Purwadi, Hermawan, Y. \& Ratih, Indraswari: Diplomasi Budaya di Kawasan Asia Tenggara. Lembaga Penelitian dan Pengabdian kepada Masyarakat Universitas Katolik Parahyangan, Bandung. pp. 4, 2014.

[3] Haigh, Anthony : Cultural Diplomacy in Europe. Council of Europe, Strasbourg. pp. 21, 1974.

[4] Barghoon, Friederich, C.: The Soviet Cultural Diplomacy: The Role of Cultural Diplomacy in Soviet Foreign Policy. Greenood Press, Westoort, Ct.pp. 10-11, 1976.

[5] U. S. Department of State: Cultural Diplomacy. International Educational Exchange Service, Bureau of International Cultural Relations, USA. pp. iv, 1959. 
[6] Panitia Pelaksana PIFAF 2016: Kerangka Acuan Kerja Polewali Mandar International Folk and Art Festival (PIFAF) 2016. pp. 11, 2016.

[7] Panitia Pelaksana PIFAF 2017 : Term of Reference Polewali Mandar International Folk and Art Festival 2017. pp. 11, 2017.

[8] Panitia Pelaksana PIFAF 2018 : Term of Reference Polewali Mandar International Folk and Art Festival 2018. pp. 10-11, 2018.

[9] Wyse, Susan E.: What is the Difference Between Qualitative Research and Quantitative Research. http://snapsurveys.com/blog/what-is the-difference-between-qualitative-researchand-quantitative-research/. Accessed on Maret 1, 2019.

[10] Bakri, Umar S.: Metode Penelitian Hubungan Internasional. Pustaka Pelajar, Yogyakarta. pp.63-64, 2016.

[11] Morgenthau, Hans J.: Politics Among Nations, The Struggle for Power and Peace. Alfred A. Knopf, New York, 1948.

[12] Nye, Joseph S.: Soft Power-The Means to Success in World Politics. Public Affairs, New York, 2004.

[13] Saputra, Muhammad DH. Defenisi Kekuatan: Hard Power dan Soft Power. https://geotimes.co.id/opini/defenisi-kekuatan-hard-power-dan-soft-power/ .Accessed on Maret 15, 2019.

[14] Nye, Joseph S.: Public Diplomacy and Soft Power. The Annals of the American Academy of Political and Social Science, Sage Journals. March 1, 2008.

[15] Direct interview with Mustari Mula as a director of the Polewali Mandar Internasional Folk and Art (PIFAF) 2018 on August 30, 2018.

[16] Direct interview with Asrul Tonga as head of the sub-division of planning and reporting for Youth, Sport and Tourism Services in PolewaliMandar Regency on March 22, 2019.

[17] www.cioff-indonesia.org. Accessed on Maret 13, 2019.

[18] Direct interview with Ridwan as a head of the section for development and promotion of the creative economy, Youth, Sports, and Tourism Services in Polewali Mandar Regency, on August 30, 2018.

[19] The speech of the Tourism Minister at the opening of the Polewali Mandar Internasional Folk and Art (PIFAF) 2018 was delivered by Afrida Pelitasari as a Head of Area III Marketing (Sulawesi, Philipina) in the Indonesia Tourism Ministry at S. Mengga stadium, Polewali Mandar District on August 1, 2018.

[20] Laporan Panitia Pelaksana Polewali Mandar Internasional Folk and Art Festival (PIFAF). Polewali Mandar Youth, Sports and Tourism Office, 2018.

[21] Laporan Panitia Pelaksana Polewali Mandar Internasional Folk and Art Festival (PIFAF). Polewali Mandar Youth, Sports and Tourism Office, 2017. 